International Journal of

Supply Chain and Logistics

(IJSCL)

PROCUREMENT PROCESS AND SERVICE DELIVERY IN THE UNITED NATIONS ORGANIZATION STABILIZATION MISSION IN THE DEMOCRATIC REPUBLIC OF CONGO (MONUSCO) ENTEBBE

SUPPORT BASE

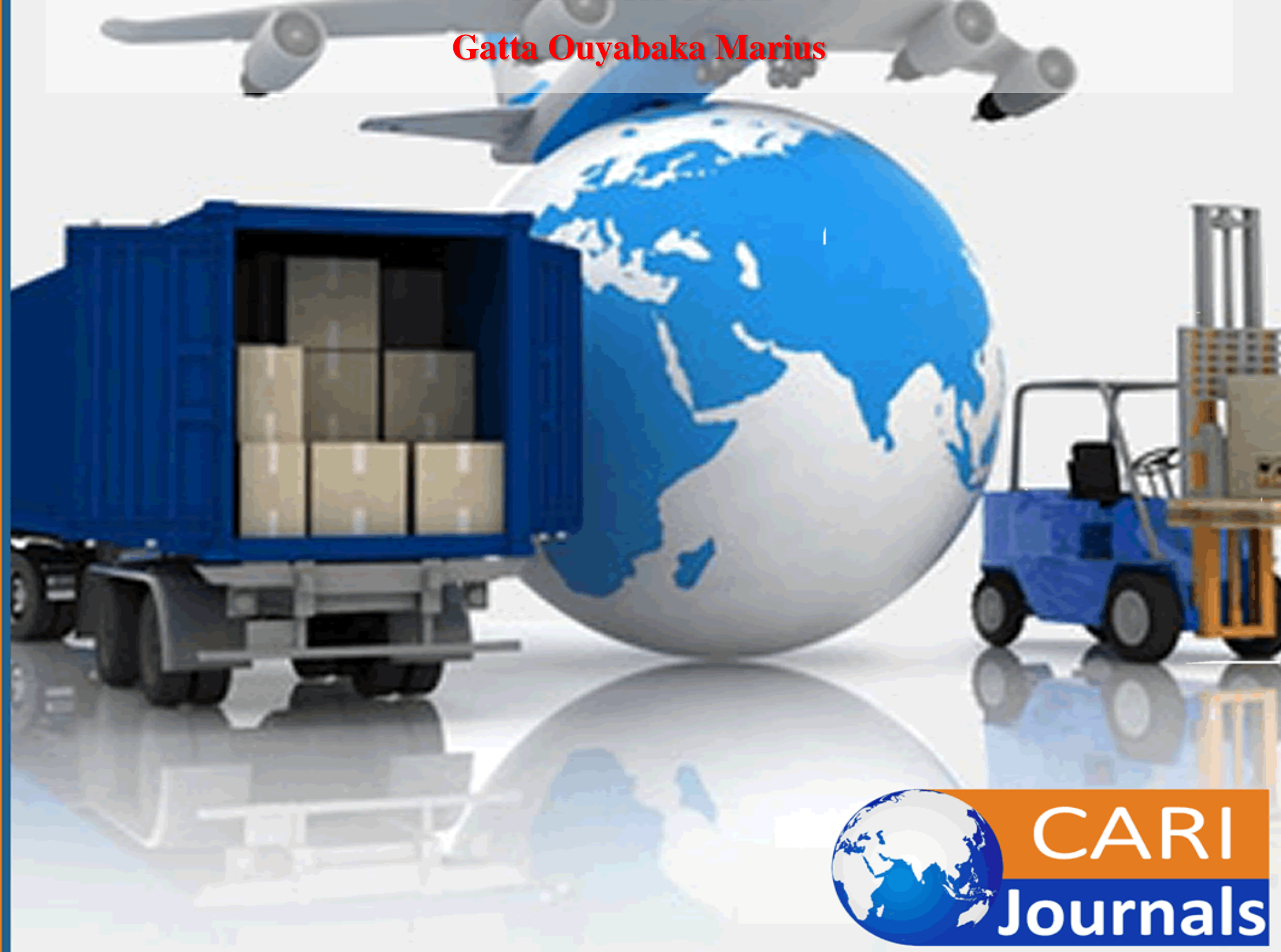




\title{
PROCUREMENT PROCESS AND SERVICE DELIVERY IN THE UNITED NATIONS ORGANIZATION STABILIZATION MISSION IN THE DEMOCRATIC REPUBLIC OF CONGO (MONUSCO) ENTEBBE SUPPORT BASE
}

\author{
1* Gatta Ouyabaka Marius \\ ${ }^{1}$ Post Graduate Student: Nkumba University \\ *Corresponding Author's E-mail: marius.gatta@gmail.com
}

\begin{abstract}
Purpose: The purpose of this study was to examine the relationship between procurement process and service delivery in MONUSCO Entebbe Support Base

Methodology: The study employed a descriptive case study design. The target population comprised of 261 employees of MONUSCO Entebbe Support Base holding international, United Nations Volunteers (UNV) and National contracts. Random and purposive sampling techniques were specifically used to select samples for this study. Data was collected using questionnaires and interview guides. The quantitative data collected was further analysed using SPSS for descriptive and inferential statistics while the qualitative data was analysed using content analysis.
\end{abstract}

Findings: The study findings showed that procurement process contributed to effective and efficient service delivery in MONUSCO. However, the found relationship between procurement process and service delivery to be very weak. It was found that contracts were awarded to suppliers who met products/materials technical specifications which ensured clear meeting of product standards and service delivery in all MONUSCO user departments. Contracts were awarded to vendors who offer lower price which implied that the bidder with the lowest price is always considered for contract award in MONUSCO ESB. The study found that some vendors did not meet all the terms of contracts as agreed at the time of contract award at the MONUSCO ESB and that to some extent the organization had not taken full appropriate correction measures against non performing vendors. This has to some extent affected the service delivery levels of MONUSCO Entebbe Support Base. It was also found that to a larger extent most vendors had a delivery schedule as per the user department requirements. This meant that the vendors draw and share the supply delivery schedule with the user departments in MONUSCO ESB.

Unique contribution to theory, practice and policy: The study recommends that the management needs to ensure that the procurement activities are accomplished in line with the outcome measures. MONUSCO Entebbe Support Base should focus on implementing strict procurement practices that must be followed with contract value thresholds dictating the procurement practices to be adopted by all MONUSCO sections.

Key words: procurement process, service delivery, MONUSCO 


\subsection{INTRODUCTION}

Procurement is an internationally recognized profession. Organisations aim at getting the best value product or service by encouraging openness, developing the relationships with potential suppliers, engaging with service users and marketing opportunities widely. The purchasing profession has been gaining recognition in developed countries faster than in the developing countries (Matechak, 2009). Worldwide, public procurement has become an issue of public attention and debate, and has been subjected to reforms, restructuring, rules and regulations.

Public procurement refers to the acquisition of goods, services and works by a procuring entity using public funds (World Bank, 1995a). Procurement process starts when an entity has identified a need and decided on its procurement requirement. Procurement goes through the process of risk assessment, seeking and evaluating alternative solutions, contract award, delivery of goods, services and works, and payment for the property and/or services and, where relevant, the ongoing management of a contract and consideration of options related to the contract. Procurement also extends to the ultimate disposal of property at the end of its useful life (Mugerwa, 2010). Furthermore, the procurement function is responsible on one hand for the identification of the end-user's needs and, by utilizing suppliers, meeting them. Therefore, by its very nature, procurement is a "service" function (Ishola, 2010).

In this study, procurement is defined as a service function provided by a dedicated team of professionals operating at the interface between the organizations' suppliers and the end-user department (s) in order to effectively and efficiently meets the supplies needs of the organization. According to Ellaram et al. (1989) in procurement, customer service outcome exists in two domains; the supplier activity domain and the end-user response domain. The study thus identifies two customers to the procurement function: internal and external i.e. the end users and the suppliers respectively. In a procurement process therefore, efforts must be dedicated to ensuring the complete satisfaction of not only the end-user or customer of a product and/or service, but, also the satisfaction of the suppliers whose products or service are incorporated into the end- user /customer order and whose performance impacts the end user satisfaction (Gordon, 2009).

Procurement process is a key function which impacts can be effective or 'ineffective' on service delivery. There is no part of local government service delivery that does not depend on procurement of goods, services and works; and yet the area remains a neglected field of research (Oboth, 2001). According to Helmsing (1995), the importance of procurement reform in almost all country's settings can be demonstrated based on its scale and role in terms of service delivery, the amount stated wasted by existing practices, reduced competition, higher prices due to market perceptions of risks, as well as the demonstrated ability of countries to capture enormous savings through concerted efforts to strengthen their procurement function (Agaba \& Shipman, 2007).

According to Harrison and Hoek (2002), procurement is further defined as the acquisition of goods, services, capabilities and knowledge required by businesses, from the right source, at the right quality, in the right quantity, at the right price and at the right time to maintain and manage the company's primary and support activities. Some of the high-level procurement activities include:

a) Determining of specifications in terms of required quality and quantities.

b) Selecting of right suppliers to provide the required goods and services. 
c) Establishing agreements with suppliers.

d) Supplier relationship management.

In order to ensure that the above activities are accomplished, as procurement measures, most companies use strict procurement practices that must be followed with contract value thresholds dictating the procurement practices to be adopted (Kourim, 2009). Generally, good procurement practices should be competitive to attract high value purchases and high value contracts. This is because procurement is the ability to source and procure goods and services required by the firm and are of the right quality, in the right quantity, at the right time, in the right place, and from the right price (Bailey \& Farmer, 2005).

Procurement in the United Nations (UN) has also undergone significant transformation since reforms were initiated in 1999. The main issues taken into consideration as part of the UN procurement reform can be found in several UN official documents, particularly Resolution A/RES/54/14 of November 1999. The Resolution specifies the direction that procurement reform initiatives need to follow in order to strengthen the principles of transparency, effectiveness and efficiency while also fully reflecting the international character of the United Nations. Procurement has evolved from a simple buying function to become recognized as a professional role within the UN as well. Procurement officers and those acting in, or supporting that function, are in a special position of trust and are held to high standards of professionalism. Development of professional and ethical competencies of UN procurement officers is recognized as an important component of the UN procurement reform process.

According to Oboth (2001), a service is a system or arrangement that supplies public needs, whereas delivery is periodic performance of a service. Therefore service delivery is a system or arrangement of periodical performance of supplying public needs. Helmsing (1995) defines service delivery as a deliberate obligatory decision by the elected or appointed officials to serve or deliver goods and services to the recipients. Heskett (1987) defines service delivery as an attitudinal or dispositional sense, referring to the internationalization of even service values and norms. Poor service delivery can be justified by ineffective procurement systems within an organization. Schooner and Whiteman, (2000) assert that the contribution of procurement policy in facilitating an efficient and effective service delivery in public sector organizations is generally undisputed in both developed and developing countries (Whiteman, 2000). Thai (2009) stated that a sound public procurement system needs to have good procurement laws and regulations. Procurement laws and regulations lead to procurement efficiency or inefficiency. Ideally, procurement laws and regulations should be clear, consistent, comprehensive, and flexible (Thai, 2009).

Strengthening service delivery is a key strategy to achieve the Millennium Development Goals. The Millennium Declaration and the Millennium Development Goals (MDGs) provide a framework for the broader goals of individual organizations of the UN system. This includes the delivery of interventions to reduce child mortality, maternal mortality, and the burden to HIV/AIDS, tuberculosis and malaria. Service provision or delivery is an immediate output of the inputs into the health sector, education sector among other sectors. Increased inputs should lead to improved service delivery and enhanced access to services. Ensuring availability and access to services is one of the main functions of a local government. Such services should meet a minimum quality standard (Development Assistance Committee 2005). 
Expectations for effective service delivery in peacekeeping missions keep increasing in most of the affected countries where UN Missions (currently there are $16 \mathrm{UN}$ peacekeeping missions in the world) operate. The largest UN peacekeeping mission is MONUSCO. The Security Council established the United Nations Organization Mission in the Democratic Republic of the Congo (MONUC) by its Resolution 1279 of 30 November 1999 (S/RES/1279; 30 November 1999). In MONUSCO as well as in all UN agencies, procurement is a function through which the organisation meets its goals and objectives by exploiting the available resource in efficient and effective way.

The MONUSCO Entebbe Support Base is the main logistic hub where $80 \%$ of the purchased commodities to support MONUSCO operations are received and thereafter dispatched all over the mission area in the Democratic Republic of Congo (DRC). In his report dated February 2016 to the Fifth Committee (the 5th Committee of the General Assembly with responsibilities for administration and budgetary matters. Based on the reports of the Fifth Committee, the General Assembly considers and approves the budget of the Organization in accordance with Chapter IV, Article 17 of the Charter of the United Nations. This function was reaffirmed by the General Assembly in its resolution 45/248 B, Sect. VI), the Chief of Entebbe Support Base has emphasized on the strategic logistic role of the ESB.

The MONUSCO Entebbe Support Base was established by MONUSCO (formerly MONUC) in 2006 near the Entebbe International Airport to provide logistics and operational support to Eastern Democratic Republic of Congo. Since its establishment, the proven operational capabilities of this facility coupled with the strategic location to neighboring missions, the reliable logistic infrastructure and the political stability of Uganda were all valuable considerations which prompted the expansion of ESB to its current capacity 9152,000 square meters). MONUSCO ESB staff in 2015 is 810, comprising of International Staff, United Nations Volunteers, Nationally recruited staff, as well as contractors and uniformed personnel (military and United Nations police).

Besides it primarily role of supporting the logistic operations in DRC, MONUSCO ESB is currently serving eleven different UN entities located in its premises. The support provided continues to expand with a call for quality services through a coordinated delivery system. Consequently, this study had identified a gap in existing empirical literature as it related to service delivery addressing procurement related issues in the logistic support provided to MONUSCO. It is against this background that the research sought to fill the gap by evaluating the procurement process and service delivery in MONUSCO: A case study of MONUSCO Entebbe Support Base (ESB).

\subsection{Statement of the problem}

Although UN has sound procurement rules, policies, guidelines and regulations to ensure best value for money and to effectively and efficiently support its operations, several reports and complaints indicated that services are not delivered to the full expectations of end-users. Within MONUSCO ESB, physical interactions with end-users and various stakeholders, reports and emails have highlighted the quality of services and/or commodities and shown growing dissatisfaction and queries towards procurement practices in MONUSCO.

In fact, several complaints pointed out the level of dissatisfaction among various stakeholders and end-users. The Regional Training Centre and Conference (RTCC) issued an Interoffice 
Memorandum dated 23 November 2011 (Ref. RSC/RTCC/2011/237) following several complaints from training participants about the quality of pens. Consequently, 114,621.00 pens valuing USD \$98756.31 were returned to stock and thereafter written - off. In May 2014, following the expansion of the Regional Service Centre Entebbe (RSCE), Supply section was urgently requested to locally acquire office furniture to support the relocation of 200 staff to ESB. Due to the urgency of the move, office furniture which was locally purchased was found to be of poor quality, resulting in raising complaints from end-users.

Following a delay in procurement planning in 2014, MONUSCO faced a shortage of office supplies, which had led for an emergency purchase of USD 150,000.00 (Ref. Fund Commitment\# 3000003042). On 23 January 2015, a vendor who had been issued a contract to supply office stationeries and supplies, failed to timely deliver the order, thus leading the Mission to urgently look for another supplier to cater for its urgent logistic requirements. Besides, the partially delivered goods were of poor quality resulting in increasing the dissatisfaction of end-users and queries about the vendor's evaluation and capacity to meet its contractual obligations. A Vendor Performance Report dated 16 June 2015 was raised and sent to Procurement for appropriate action against the vendor without any success.

It is based on such evidence that the study was carried out to investigate the role of procurement process in ensuring effective service delivery in MONUSCO Entebbe Support Base.

\subsection{Research Objective}

To examine the relationship between procurement process and service delivery in MONUSCO Entebbe Support Base

\subsection{LITERATURE REVIEW}

\subsection{Theoretical Review}

\subsubsection{Institutional Theory}

According to Scott (2004), institutions are composed of cultural-cognitive and regulative elements that, together with associated activities and resources give meaning to life. He further explains the three pillars of institutions as regulatory, normative and cultural cognitive. The regulatory pillar emphasizes the use of rules, laws and sanctions as enforcement mechanism, with expedience as basis for compliance. The normative pillar refers to norms (how things should be done) and values (preferred or desirable), social obligation being the basis of compliance. The cultural-cognitive pillar rests on shared understanding (common beliefs, symbols, shared understanding). This theory is very important when it comes to the implementation of sustainable procurement policy and practice in organizations that serve the public. This is a matter of organizational culture and the degree to which the prevailing climate in an organization is supportive of sustainability and/or of change in general. In other respects, this dimension includes the extent to which there is support for SP at senior levels in an organization and the degree to which organizational processes and structures support, or retard, the development of SP (Brammer \& Walker, 2007).

\subsubsection{Socio-economic Theory}

Sutinen and Kuperan (1999) propounded the socio-economic theory of compliance by integrating economic theory with theories from psychology and sociology to account for moral 
obligation and social influence as determinants of individuals' decisions on compliance. According to Lisa (2010) psychological perspectives provide a basis for the success or failure of organizational compliance. Wilmshurst and Frost (2000) also add that the legitimacy theory postulates that the organization is responsible to disclose its practices to the stakeholders, especially to the public and justify its existence within the boundaries of society. This theory, which focuses on the relationship and interaction between an organization and the society, provides a sufficient and superior lens for understanding government procurement system (Hui et al., 2011). From this theory, one can understand the policy, planning and sustainable procurement practices in public institutions and their influence on service delivery to the society.

\subsection{Procurement Process}

According to (Simchi et al., 2009), the procurement function is responsible on one hand for the identification of the end-user's needs and, by utilizing suppliers, meeting them. By its very nature therefore, procurement is a "service" function (Ishola, 2010).Hence, in this paper we define procurement as a service function provided by a dedicated team of professionals operating at the interface between the organisation's suppliers and the end-user department (s) in order to effectively and efficiently meet the supplies needs of the organisation. According to Ellaram et al. (1989) in procurement customer service outcome exists in two domains; the supplier activity domain and the end-user response domain.

We, thus, identify two customers to the procurement function: internal and external i.e. the end users and the suppliers respectively. In a procurement process therefore, efforts must be dedicated to ensuring the complete satisfaction of not only the end-user or customer of a product and/or service, but, also the satisfaction of the suppliers whose products or service are incorporated into the end- user /customer order and whose performance impacts the end user satisfaction (Gordon, 2009). In the United Nations Procurement Manual, Revision 7 (2013) the purchasing process for companies breaks down into eight clear steps. In the first step the company identifies a need, for which the answer is the purchase of a product. The final step is the execution of a purchase contract. The steps in between build an organized, informed process that results in the company purchasing the right product for the need from a qualified supplier whose product is the most durable for the price. 


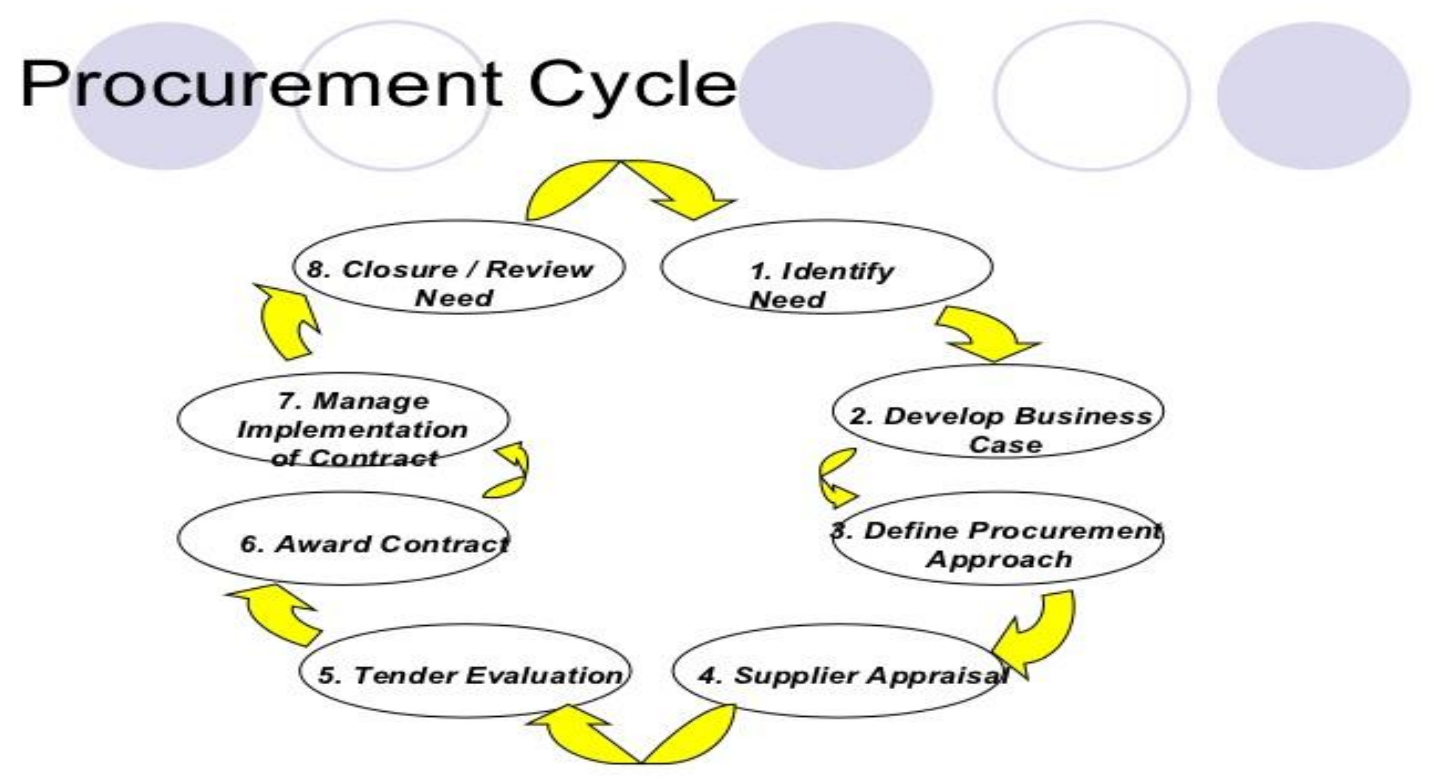

\section{Figure 1: Procurement Cycle flow chart according to the UN Procurement Manual}

According the United Nations Procurement Manual, Revision 7 (2013) The UN procurement process involves a wide-range of activities including: acquisition planning; drafting; reviewing or approving Specifications, SOWs and TORs; identifying, registering and evaluating Vendors; preparing and developing Solicitations; evaluating Bids or Proposals; Source Selection; negotiating price or terms and conditions of Contracts; reviewing and approving awards of Contracts; providing legal services including drafting Contracts; signing Contracts and Purchase Orders; receiving and inspecting goods or services; performing oversight services; managing Contracts; reviewing Vendor Performance; certifying, approving and making payments pursuant to large and complex Contracts; and handling Vendor protests or disputes regarding the procurement process.

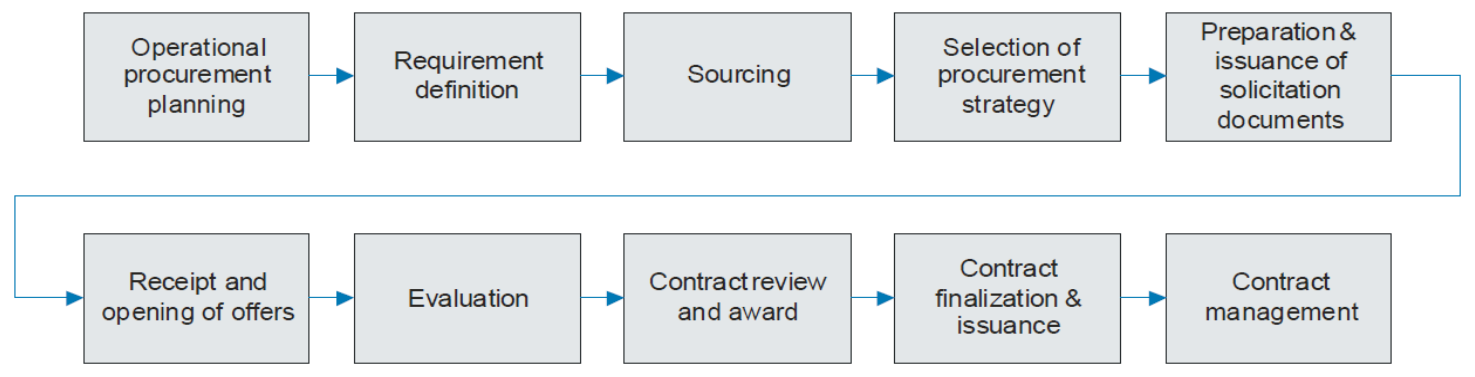

Figure 2: Procurement Process Flow Chart of the United Nations 
A key aspect of the procurement process outlined in UN Procurement Practitioner's Handbook (2006) Manual begins with the registration of potential recipients of UN Solicitation Documents. It is the procurement staff responsibility to further develop the sourcing by identifying vendors that will meet the Requisitioner's requirements. The UN in its sole discretion determines whether a Vendor is eligible for registration, and continues to remain eligible, for the purpose of establishing a pool of prospective UN Vendors. Such Vendors may be invited to participate in a particular Solicitation. Determination of eligibility for registration is a UN prerogative. Thereafter, the UN receives and evaluates responses to Solicitations, determining whether the Vendor is both qualified and meets the requirements of Financial Rule 105.15(a) for Bids or (b) for Proposals. The UN decides which Vendor to select and notifies it of its intention to award a Contract. The successful Bidder, following Contract negotiations (if any) and the signature of a Contract, would then become a UN contract or whose relationship vis-à-vis the UN is governed by the contract formation processes outlined in this Procurement Manual. Unsuccessful Bidders will be notified accordingly and may be granted a debriefing.

\subsection{Service Delivery}

According to Oboth (2001), in as far as the Local Government Act, the constitution and any other statutes that are studied, there is no definition of the phrase (service delivery) either deliberately or ignorantly. However, he said, Service is a system or arrangement that supplies public needs whereas delivery is periodical performance of a service. Therefore service delivery is a system or arrangement of periodical performance of supplying public needs. Helmsing (1995) in his study defines service delivery as a deliberate obligatory decision by the elected or appointed officials to serve or deliver goods and services to the recipients. Heskett (1987) defines service delivery as an attitudinal or dispositional sense, referring to the internationalization of even service values and norms.

\subsubsection{Customer Service Delivery}

According to Holberton (1991, as cited in Armstrong, 1999) customer service are the activities involved in ensuring that a product or a service is delivered to the customer on time and in the right quantity by the order taking department of the organization. On the other hand, Helmsing (1995) in his study defines service delivery as a deliberate obligatory decision by the elected or appointed officials to serve or deliver goods and services to the recipients. Thus, considering the above definitions, we define customer service delivery as the deliberate obligatory management of activities involved in ensuring customer service by means of meeting the needs and expectation of the customer, as defined by the customer. For, according to Khattab (2005), a major role of any business is to meet its customers' needs and expectations. Failure to which is assumed to result in customer dissatisfaction. Thus any business function looking for success in today's market place must be customer centered -aim at delivering superior value to its target customer.

Since the objectives of the procurement function are: to buy the right quality, in the right quantity from the right source, delivered to the right place at the right time and at the right price (Lysons, 2000). (Christopher, 2002) asserts that in general the main variables, therefore, in each purchasing process and decision are: quality, delivery and price service package. It is against these variables that the procurement entity has basically to function within in order to satisfy its internal customers, the end-users. Parasuram et al. (1985, as cited in Wagube, 2011) gave the 
indicators of service delivery to include: responsiveness (the willingness or readiness to provide services) and communication (keeping the customer informed in a language they understand and listening to them). (Kakura, 2004) adds completeness (should contain all the features that satisfy the customers' expectations). While Balunywa (1998) adds conformance (this is the degree to which a service design and operating characteristics meet established standards).

\subsubsection{Procurement Policy and Servicer Delivery}

Procurement policy is a factor influencing service delivery. Nichols (2002) argues that procurement policy is one of the primary functions of procurement with a potential to contribute to the success of government operations and improved service delivery. It is a function that sets in motion the entire acquisition or procurement process of acquiring services in governments (Lambsdorff, 2007). Schooner and Whiteman, (2000) assert that the contribution of procurement policy in facilitating an efficient and effective service delivery in public sector organizations is generally undisputed in both developed and developing countries. Thai (2009) started that a sound public procurement system needs to have good procurement laws and regulations. In practice and theory, public procurement laws and regulations have been considered as one of the most important pillars of a sound procurement system. Procurement laws and regulations lead to procurement efficiency or inefficiency. There has always been a debate about a procurement legal framework that hinders or helps procurement discretion (Thai, 2009)

\subsubsection{Quality Service Delivery Indicators}

Parasuram et al. (1985) gave the indicators of service delivery to include reliability, tangibility, responsiveness, accessibility, and empathy as discussed below:

Accessibility: Failure to have access to the use of facilities will render some limited services since they are not used optimally and yet services depend on the use of the facilities (Ssemayengo, 2005). Services that are not accessible are regarded as being of poor quality and those that can be easily accessible are regarded as high quality services.

Reliability: This is the probability of a service failing within a specified time period. Among the common measures of reliability are the average time to first failure, the average time between failures, and the failure rate per unit time (Balunywa, 1998). For example if a battery is to give 1.5 volts either in the mornings or evenings. This voltage should be 1.5 volts, if it varies, the battery will be unreliable and considered poor by not delivering the required services (Kakuru, 2004).

Completeness: For a service to be perceived as service, it should contain all the features that satisfy the customers' expectation (Kakuru, 2004). It should have all its primary operating characteristics with all the measurable attributes so as to be ranked as high service (Balunywa, 1998).

Timeliness: Delay in service delivery will make the services to lose the meaning and hence a service should be offered in time before it becomes irritating to the consumer (Ssemayengo, 2005). Services which are delivered in time are said to be of good service and those that are not delivered in time are said to have poor service.

Conformance: This is the degree to which a service design and operating characteristics meet established standards. Good service is therefore equated with operation within a tolerance degree (Balunywa, 1998). The question here is that can the service achieve the core purpose for which it 
is intended? If the service performs as expected and intended it will be considered good service offered.

Safety: How safe is it to use the service? Does it protect users before, during and after use? Certain services like roads may be a problem when being used. Some services are also not very safe when being used as they easily cause harm to the users. Services that are not safe to use are considered poor services and those that are safe to use are looked at as expected services (Kakuru, 2004).

\subsection{Procurement Process and Service Delivery}

All procurements regardless of their value or complexity follow a standard sequence of actions. This is known as the procurement process (Bashuna, 2013). The procurement process is a series of steps involved in the process of acquiring goods for sale or use by a company or agency. It starts with identifying the need for a given product, moves through the process of purchase and delivery (Basheka, 2004). Unlike strategic procurement which has a long-term focus; tactical procurement deals with the administration of procurement actions. A buyer needs to know some fundamentals of procurement for this tactical purchase. The buyer must first identify the product, service, and /or supplier with an acceptable probability of being satisfactory in all aspects of the transaction and then achieve the lowest cost for that product or with that supplier (Basheka, 2004).

The component of the tactical procurement process as discussed earlier can be summarized as pre-procurement and actual procurement activities. Although it is important to ensure that the tactical procurement process is effectively done to improve service delivery in areas of quality management, cost and time of delivering of services, Basheka (2004) contends that the main challenge facing most procurement entities engaged in the tactical process is how to determine the length of each step in the procurement process and its duration. Failure to determine its length can pose negative implication on cost, quality and time delivering services, hence leading to poor service delivery management.

\subsection{RESEARCH METHODLOGY}

The study employed a descriptive case study design. The study population comprised of 261 staff members holding international, United Nations Volunteers (UNV) and National contracts. Both probability and non-probability sampling methods were used to select the respondents. Random and purposive sampling techniques were used to select samples for this study. Two research instruments namely self-administered questionnaires and interview guides were used for data collection. The quantitative data collected was further analysed using SPSS where descriptive and inferential statistics were generated while the qualitative data was analysed using content analysis.

\subsection{RESULTS AND FINDINGS}

\subsection{Response Rate}

A total of 158 questionnaires administered to the selected respondent where a total of 133 questionnaires were properly filled and returned. This represented an overall successful response rate of $84.18 \%$ which was very adequate for this study. 


\subsection{Relationship between Procurement Process and Service Delivery in MONUSCO ESB}

The objective of this study was to examine the relationship between procurement process and service delivery in MONUSCO ESB. The respondents were asked to respond to various statements on a given scale. The findings are as in the following sub sections.

\subsubsection{Awarding of Contracts to Suppliers who meet Products/Materials Technical Specifications}

If pre-qualification has not preceded the solicitation process, the selected supplier's qualification should be checked prior to contract award. This is usually called post-qualification. The respondents were asked whether contract is awarded to suppliers who meet our products/materials technical specifications and responses obtained are shown in the Table 1:

Table 1: Awarding of Contracts to Suppliers who meet Products/Materials Technical Specifications

\begin{tabular}{lccc}
\hline Statement & Response & Frequency & Percent \\
\hline & Strongly Disagree & 1 & .8 \\
& Disagree & 10 & 7.5 \\
& Neutral & 12 & 9.0 \\
Contract is awarded to suppliers who meet & Agree & 52 & 39.1 \\
our products/materials technical & Strongly Agree & 58 & 43.6 \\
specifications & Total & $\mathbf{1 3 3}$ & $\mathbf{1 0 0 . 0}$ \\
\hline
\end{tabular}

Results in the table above show that, $1(0.8 \%)$ strongly disagreed, 10 (7.5\%) disagreed, 12 $(9.0 \%)$ were neutral, $52(39.1 \%)$ agreed and $58(43.6 \%)$ of them strongly agreed. Results obtained indicate that $110(82.7 \%)$ of the respondents generally agreed that indeed contract is awarded to suppliers who meet our products/materials technical specifications. During the interviews respondents revealed "the suppliers are awarded contracts based on their level of meeting the product/materials technical specifications". This has ensured clear meeting of product standards and service delivery in all MONUSCO user departments.

\subsubsection{Awarding of Contracts to Vendors who offer Lower Price}

The respondents were further asked whether in MONUSCO, contracts are awarded to vendors who offer lower price and responses obtained are shown in the Table 2:

Table 2: Awarding of Contracts to Vendors who offer Lower Price

\begin{tabular}{lccc}
\hline Statement & Response & Frequency & Percent \\
\hline & Strongly Disagree & 6 & 4.5 \\
& Disagree & 13 & 9.8 \\
& Neutral & 19 & 14.3 \\
& Agree & 28 & 21.1 \\
In MONUSCO, Contracts are awarded to & Strongly Agree & 67 & 50.1 \\
vendors who offer lower price & Total & $\mathbf{1 3 3}$ & $\mathbf{1 0 0 . 0}$ \\
\hline
\end{tabular}

Results in the table above show that, 6 (4.5\%) strongly disagreed, 13 (9.8\%) disagreed, 19 $(14.3 \%)$ were neutral, $28(21.1 \%)$ agreed and $67(50.1 \%)$ of them strongly agreed. Results 
obtained indicate that $95(71.2 \%)$ of the respondents generally agreed that Contracts are awarded to vendors who offer lower price. During the interviews respondents revealed "the suppliers are awarded contracts based on the lowest price offers for the various services and goods to be procured by MONUSCO user departments at the Entebbe Support Base". This implies that the bidder with the lowest price is always considered for contract award in MONUSCO ESB.

\subsubsection{Meeting all the Terms of Contracts by MONUSCO vendors}

The respondents were further asked whether MONUSCO vendors meet all the terms of contracts and responses obtained are shown in the Table 3:

Table 3: Meeting all the Terms of Contracts by MONUSCO vendors

\begin{tabular}{lccc}
\hline Statement & Response & Frequency & Percent \\
\hline & Strongly Disagree & 9 & 6.8 \\
& Disagree & 69 & 51.9 \\
& Neutral & 23 & 17.3 \\
& Agree & 24 & 18.0 \\
MONUSCO vendors meet all the terms of & Strongly Agree & 8 & 6.0 \\
contracts & Total & $\mathbf{1 3 3}$ & $\mathbf{1 0 0 . 0}$ \\
\hline
\end{tabular}

Results in the table above show that, 9 (6.8\%) strongly disagreed, 69 (51.9\%) disagreed, 23 $(17.3 \%)$ were neutral, $24(18.0 \%)$ agreed and $8(6 \%)$ of them strongly agreed. Results obtained indicate that $78(58.6 \%)$ of the respondents generally disagreed that MONUSCO vendors meet all the terms of contracts. During the interviews respondents revealed "in some cases, some suppliers are awarded contracts yet they do not meet all the contract terms as agreed by the contract committee". This implies that some vendors do not meet all the terms of contracts as agreed at the time of contract award in MONUSCO ESB.

\subsubsection{Satisfaction with Vendors dealing with Respective Sections}

The respondents were further asked whether they are happy with the vendors their section deals with in MONUSCO and responses obtained are shown in the Table 4:

Table 4: Satisfaction with Vendors dealing with Respective Sections

\begin{tabular}{lccc}
\hline Statement & Response & Frequency & Percent \\
\hline & Strongly Disagree & 2 & 1.5 \\
& Disagree & 67 & 50.4 \\
& Neutral & 35 & 26.3 \\
& Agree & 23 & 17.3 \\
I am happy with the vendors my section & Strongly Agree & 6 & 4.5 \\
deals with & Total & $\mathbf{1 3 3}$ & $\mathbf{1 0 0 . 0}$ \\
\hline
\end{tabular}

Results in the table above show that, 2 (1.5\%) strongly disagreed, 67 (50.4\%) disagreed, 35 $(26.3 \%)$ were neutral, $23(17.3 \%)$ agreed and $6(4.5 \%)$ of them strongly agreed. Results obtained indicate that $69(51.9 \%)$ of the respondents generally disagreed that they are happy with the vendors their section deals with in MONUSCO. The results obtained imply that to a larger extent the staff of MONUSCO are not very happy with the vendors their respective section deals with. 
This means the vendors do not adequately meet the contract terms and conditions which affects service delivery in the user departments of MONUSCO ESB.

\subsubsection{All Vendors Having Clear Delivery Schedules}

The study went ahead to ask the respondents whether all vendors have a clear delivery schedule in MONUSCO ESB and responses obtained are shown in the table 5;

Table 5: All Vendors Having Clear Delivery Schedules

\begin{tabular}{lccc}
\hline Statement & Response & Frequency & Percent \\
\hline & Strongly Disagree & 1 & .8 \\
& Disagree & 4 & 3.0 \\
& Neutral & 10 & 7.5 \\
& Agree & 78 & 58.6 \\
All vendors have a clear delivery schedule & Strongly Agree & 40 & 30.1 \\
\hline
\end{tabular}

Results in the table above show that, $1(0.8 \%)$ strongly disagreed, $4(3.0 \%)$ disagreed, $10(7.5 \%)$ were neutral, $78(58.6 \%)$ agreed and $40(30.1 \%)$ of them strongly agreed. Results obtained indicate that $118(88.7 \%)$ of the respondents generally agreed that All vendors have a clear delivery schedule in MONUSCO ESB. The results obtained imply that to a larger extent most vendors have a delivery schedule as per the user department requirements. This means that the vendors draw and share the supply delivery schedule with the user departments in MONUSCO ESB.

\subsubsection{Taking Appropriate Correction Measures against Non-Performing Vendors}

The study also asked the respondents whether MONUSCO takes appropriate correction measures against non-performing vendors in MONUSCO ESB and responses obtained are shown in the Table 6:

Table 6: Taking Appropriate Correction Measures against Non-Performing Vendors

\begin{tabular}{lccc}
\hline Statement & Response & Frequency & Percent \\
\hline & Strongly Disagree & 16 & 12.0 \\
& Disagree & 50 & 37.6 \\
& Neutral & 17 & 12.8 \\
\multirow{2}{*}{ MONUSCO takes appropriate correction } & Agree & 30 & 22.6 \\
measures against non-performing vendors & Strongly Agree & 20 & 15.0 \\
& Total & $\mathbf{1 3 3}$ & $\mathbf{1 0 0 . 0}$ \\
\hline
\end{tabular}

Results in the table above show that, 16 (12\%) strongly disagreed, 50 (37.6\%) disagreed, 17 $(12.8 \%)$ were neutral, $30(22.6 \%)$ agreed and $20(15.0 \%)$ of them strongly agreed. Results obtained indicate that $66(49.6 \%)$ of the respondents generally disagreed that MONUSCO takes appropriate correction measures against non-performing vendors in MONUSCO ESB. The results obtained imply that to some extent the organization has not taken full appropriate correction measures against non-performing vendors. This has to some extent affected the service delivery levels of MONUSCO Entebbe Support Base. 


\subsubsection{Undertaking of Supplier Audits to Correct Compliance Errors}

Procurement planning procedures may be convenient and useful tools, but the planning effort will succeed only with the complete commitment and involvement of top management. This also calls for measurement of the effectiveness to ensure proper business controls by conducting periodic supplier audits to correct compliance errors (Lisa: 2010). The study therefore asked the respondents whether supplier audits are undertaken to correct compliance errors at the ESB and responses obtained are shown in the Table 7:

Table 7: Undertaking of Supplier Audits to Correct Compliance Errors

\begin{tabular}{lccc}
\hline Statement & Response & Frequency & Percent \\
\hline & Strongly Disagree & 8 & 6.0 \\
& Disagree & 17 & 12.8 \\
& Neutral & 12 & 9.0 \\
Supplier audits are undertaken to correct & Agree & 70 & 52.6 \\
compliance errors & Strongly Agree & 26 & 19.5 \\
& Total & $\mathbf{1 3 3}$ & $\mathbf{1 0 0 . 0}$ \\
\hline
\end{tabular}

Results in the table above show that, 8 (6\%) strongly disagreed, $17(12.8 \%)$ disagreed, $12(9.0 \%)$ were neutral, $70(52.6 \%)$ agreed and $26(19.5 \%)$ of them strongly agreed. Results obtained indicate that $96(72.1 \%)$ of the respondents generally agreed that supplier audits are undertaken to correct compliance errors in MONUSCO ESB. The results obtained imply that indeed the user departments in collaboration with the procurement section have always conducted supplier audits for all pre-qualified vendors in MONUSCO ESB. This has reduced on the delivery of substandard materials and products as well increased adherence to compliance regulations.

\subsubsection{Existence of Guidelines on Process Approval in MONUSCO}

The study also asked the respondents as to whether there are guidelines on process approval in MONUSCO ESB and responses obtained are shown in Table 8. Results in the table above show that, $2(1.5 \%)$ strongly disagreed, $13(9.8 \%)$ were neutral, $71(53.4 \%)$ agreed and $47(35.3 \%)$ of them strongly agreed. Results obtained indicate that $118(88.7 \%)$ of the respondents generally agreed that there are guidelines on process approval in MONUSCO ESB. The results obtained imply that indeed the user departments have been provided with procurement guidelines to be followed in all procurement activities of MONUSCO ESB. The results obtained are in line with those of Seminega (2012) from Kenya who reported that in most developing countries, the Procurement Officers are provided with procurement guidelines, manuals or a handbook which he argues must be complied.

Table 8: Existence of Guidelines on Process Approval in MONUSCO

\begin{tabular}{lccc}
\hline Statement & Response & Frequency & Percent \\
\hline & Disagree & 2 & 1.5 \\
& Neutral & 13 & 9.8 \\
& Agree & 71 & 53.4 \\
There are guidelines on process approval & Strongly Agree & 47 & 35.3 \\
in MONUSCO & Total & $\mathbf{1 3 3}$ & $\mathbf{1 0 0 . 0}$ \\
\hline
\end{tabular}




\subsubsection{Awareness of All Delivery Times for Materials in Respective Sections}

The lack of delivery schedules compels the organization to make emergency purchases to cater for the deficits thus negatively affecting the performance of the organization. Therefore the respondents were asked as to whether they are aware of all delivery times for materials their respective sections. Responses obtained are summarized in the table 9:

Table 9: Awareness of All Delivery Times for Materials in Respective Sections

\begin{tabular}{lccc}
\hline Statement & Response & Frequency & Percent \\
\hline & Strongly Disagree & 14 & 10.5 \\
& Disagree & 50 & 37.6 \\
& Neutral & 16 & 12.0 \\
I am aware of all delivery times for & Agree & 37 & 27.8 \\
materials in my section & Strongly Agree & 16 & 12.0 \\
\hline
\end{tabular}

Results in the table above show that, 14 (10.5\%) strongly disagreed, 50 (37.6\%) disagreed, 16 $(12 \%)$ were neutral, $37(27.8 \%)$ agreed and $16(12 \%)$ of them strongly agreed. Results obtained indicate that $64(48.1 \%)$ of the respondents generally disagreed that they are fully aware of the delivery times for materials in their respective sections in MONUSCO ESB. The results obtained imply that some staff of MONUCO are not aware of the delivery schedules for materials used in the emergency operations or peace keeping operations. The results obtained imply that to a greater extent they are not fully involved in the delivery scheduling of the procurement activities.

\subsubsection{MONUSCO's Vendors not Meeting the Delivery Time}

The consequences of poor or lack of procurement planning can never therefore be amusing. The World Bank Country Procurement Assessment Report (2004) summarized some of these consequences as procurement failing to timely meet the actual needs of user department. So the study asked the respondents whether MONUSCO's vendors do not meet the delivery time and responses obtained are summarized in Table 10.

Table 10: MONUSCO's Vendors not Meeting the Delivery Time

\begin{tabular}{lccc}
\hline Statement & Response & Frequency & Percent \\
\hline & Strongly Disagree & 7 & 5.3 \\
& Disagree & 14 & 10.5 \\
& Neutral & 27 & 20.3 \\
& Agree & 50 & 37.6 \\
MONUSCO's vendors do not meet the & Strongly Agree & 35 & 26.3 \\
delivery time & Total & $\mathbf{1 3 3}$ & $\mathbf{1 0 0 . 0}$ \\
\hline
\end{tabular}

Results in the table above show that, 7 (5.3\%) strongly disagreed, 14 (10.5\%) disagreed, 27 $(20.3 \%)$ were neutral, $50(37.6 \%)$ agreed and $35(26.3 \%)$ of them strongly agreed. Results obtained indicate that $85(63.9 \%)$ of the respondents generally agreed that to a lager extent MONUSCO's vendors do not meet the delivery time as agreed in the contract. During the interviews, the respondents noted that "in some cases the materials needed for emergency operations are delivery after the agreed time and this has affected the levels of service delivery 
offered by the MONUSCO ESB". This is the reason as to whey even most staff of MONUSCO are not aware of the delivery schedules for materials used in the emergency operations or peace keeping operations.

\subsubsection{Cases of Vendors Failing to Deliver the Materials Ordered}

According to Drabkin and Thai (2003) as a function, procurement planning endeavours to answer how timely procurement or failure affects the user of the item(s). The respondents were therefore asked whether there are many cases of vendors failing to deliver the materials ordered.

Table 11: Cases of Vendors Failing to Deliver the Materials Ordered

\begin{tabular}{lccc}
\hline Statement & Response & Frequency & Percent \\
\hline & Strongly Disagree & 12 & 9.0 \\
& Disagree & 7 & 5.3 \\
& Neutral & 23 & 17.3 \\
& Agree & 40 & 30.1 \\
There are many cases of vendors failing to & Strongly Agree & 51 & 38.3 \\
deliver the materials ordered & Total & $\mathbf{1 3 3}$ & $\mathbf{1 0 0 . 0}$ \\
\hline
\end{tabular}

\section{Source: Primary data}

Results in the table above show that, 12 (9\%) strongly disagreed, 7 (5.3\%) disagreed, 23 (17.3\%) were neutral, $40(30.1 \%)$ agreed and $51(38.3 \%)$ of them strongly agreed. Results obtained indicate that $91(68.4 \%)$ of the respondents generally agreed that to a lager there are many cases of vendors failing to deliver the materials ordered at MONUSCO ESB. During the interviews, the respondents noted that "it's true in some departments; there are cases where vendors fail to deliver the materials ordered as per the user department requirements". This has negatively affected the operations of especially the peacekeeping missions of the MONUSCO.

\subsubsection{Importance of Delivery Time for Materials/Commodities among Staff}

An effective public procurement process ensures the availability of the right goods and services in the right quantities, available at the right time, for the right customers and at reasonable prices, and at recognizable standards of quality (WHO: 2007). The respondents were therefore asked whether the delivery time for materials/commodities is not important to them and responses obtained are summarized in the Table 12. Results in the table 12 show that, $90(67.7 \%)$ strongly disagreed, 34 (25.6\%) disagreed, 5 (3.8\%) were neutral, $2(1.5 \%)$ agreed and $2(1.5 \%)$ of them strongly agreed. Results obtained indicate that $124(93.2 \%)$ of the respondents generally disagreed that the delivery time for materials/commodities is not important to them. The results obtained indicate that at least majority staff feel that the delivery time for materials/commodities is very important to them in MONUSCO ESB. During the interviews, the respondents noted that "in actual sense they feel concerned about the delayed delivery of requisitioned for materials from the various vendors of MONUSCO ESB". They further reported that there are many cases where vendors fail to deliver the materials ordered on time as per the user department requirements". This has negatively affected the operations of user departments at MONUSCO ESB. 
Table 12: Importance of Delivery Time for Materials/Commodities among Staff

\begin{tabular}{lccc}
\hline Statement & Response & Frequency & Percent \\
\hline & Strongly Disagree & 90 & 67.7 \\
& Disagree & 34 & 25.6 \\
& Neutral & 5 & 3.8 \\
Delivery time for materials/commodities & Agree & 2 & 1.5 \\
is not important to me & Strongly Agree & 2 & 1.5 \\
\hline
\end{tabular}

4.2.13 Failure of Vendors to Deliver the Right Goods, at the Right Time and the Right Quantity

MONUSCO ESB as service provider entity of the UN peace keeping missions they need to acquire goods, services and works of the right quality, at the right time, in the right quantity, from the right source and at the right price. The respondents were therefore asked whether Vendors do not deliver the right goods, at the right time and the right quantity and responses obtained are summarized in the Table 13:

Table 13: Failure of Vendors to Deliver the Right Goods, at the Right Time and the Right Quantity

\begin{tabular}{lccc}
\hline Statement & Response & Frequency & Percent \\
\hline & Strongly Disagree & 27 & 20.3 \\
& Disagree & 19 & 14.3 \\
& Neutral & 16 & 12.0 \\
Vendors do not deliver the right goods, at & Agree & 31 & 23.3 \\
the right time and the right quantity & Strongly Agree & 40 & 30.1 \\
\hline
\end{tabular}

Results in the table above show that, 27 (20.3\%) strongly disagreed, 19 (14.3\%) disagreed, 16 (12\%) were neutral, 31 (23.3\%) agreed and 40 (30.1\%) of them strongly agreed. Results obtained indicate that $71(53.4 \%)$ of the respondents generally agreed that vendors do not deliver the right goods, at the right time and the right quantity. The results obtained indicate that at least majority staff feels that vendors do not deliver the right goods, at the right time and the right quantity in MONUSCO ESB. During the interviews, the respondents noted that "there are many cases where vendors fail to deliver the materials ordered on time as per the user department requirements". This has negatively affected the operations of user departments in MONUSCO ESB.

\subsubsection{Involvement of Staff in Following Up Materials Ordered}

In all situations, the procurement officer is responsible for following up and ensuring that the actions of the supplier and the UN organization are in line with the contractual responsibilities. The respondents were therefore asked whether they are involved in following up materials ordered and responses obtained are summarized in the Table 14: 
Table 14: Involvement of Staff in Following Up Materials Ordered

\begin{tabular}{lccc}
\hline Statement & Response & Frequency & Percent \\
\hline & Strongly Disagree & 21 & 15.8 \\
& Disagree & 33 & 24.8 \\
& Neutral & 25 & 18.8 \\
& Agree & 43 & 32.3 \\
I am involved in following up materials & Strongly Agree & 11 & 8.3 \\
ordered & Total & $\mathbf{1 3 3}$ & $\mathbf{1 0 0 . 0}$ \\
\hline
\end{tabular}

Results in the table above show that, 21 (15.8\%) strongly disagreed, 33 (24.8\%) disagreed, 25 (18.8\%) were neutral, $43(32.3 \%)$ agreed and $11(8.3 \%)$ of them strongly agreed. Results obtained indicate that $54(40.6 \%)$ of the respondents generally agreed that to a lager extent they are involved in following up materials ordered in their respective sections in MONUSCO ESB. Results obtained indicate that indeed some staff are involved in following up materials ordered in their respective sections. During the interviews, the respondents noted that "they are involved in order to ascertain the delivery of right materials as ordered by the user departments". They revealed that this has helped in checking conformity to material specifications as requested for the respective user departments in MONUSCO.

\subsubsection{Buying of Substandard Materials which do not Fit for Purpose}

According to Baily P. et al; (2008) standards required in procurement are high quality service, economy and efficiency and fairness in completion. Thus a procedure must be followed and applicable to all contracts for goods and works. Therefore, respondents were asked to opine whether MONUSCO buys substandard materials which do not fit for purpose and responses obtained are summarised in the Table 15.

Table 15: Buying of Substandard Materials which do not Fit for Purpose

\begin{tabular}{lccc}
\hline Statement & Response & Frequency & Percent \\
\hline & Strongly Disagree & 27 & 20.3 \\
& Disagree & 18 & 13.5 \\
& Neutral & 11 & 8.3 \\
& Agree & 36 & 27.1 \\
MONUSCO buys substandard materials & Strongly Agree & 41 & 30.8 \\
which do not fit for purpose & Total & $\mathbf{1 3 3}$ & $\mathbf{1 0 0 . 0}$ \\
\hline
\end{tabular}

The results show that, $27(20.3 \%)$ strongly disagreed, 18 (13.5\%) disagreed, $11(8.3 \%)$ were neutral, $36(27.1 \%)$ agreed and $41(30.8 \%)$ of them strongly agreed. Results obtained indicate that $77(57.9 \%)$ of the respondents generally agreed that MONUSCO buys substandard materials which do not fit for purpose in the respective sections in MONUSCO ESB. Results obtained indicate that indeed to some extent MONUSCO buys substandard materials which do not fit for purpose. A review of MONUSCO documents revealed that for example in May 2014, following the expansion of the Regional Service Centre Entebbe (RSCE), Supply section was urgently requested to locally acquire office furniture to support the relocation of 200 staff to MONUSCO ESB. Due to the urgency of the move, office furniture which was locally purchased was found to 
be of poor quality, resulting in raising complaints from end-users. This therefore resulted to scenarios whether the organization buys substandard materials which do not fit for purpose in the respective user departments in MONUSCO.

\subsubsection{Effect of Failure by the Vendor to Deliver on Time on Operations of Respective Sections}

More still respondents were asked to opine whether failure by the vendor to deliver on time does not affect operations in their respective sections at MONUSCO and responses obtained are summarised in the Table 16. Results in the table above show that, 95 (71.4\%) strongly disagreed, $23(17.3 \%)$ disagreed, $8(6.0 \%)$ were neutral, $4(3.0 \%)$ agreed and $3(2.3 \%)$ of them strongly agreed. Results obtained indicate that $118(88.7 \%)$ of the respondents generally disagreed that failure by the vendor to deliver on time does not affect operations in their respective sections in MONUSCO. Results obtained indicate that indeed failure by the vendor to deliver on time does affect operations in their respective sections at MONUSCO. A review of MONUSCO documents revealed that for example on 23 January 2015, a vendor who has been issued a contract to supply office stationeries and supplies, failed to timely deliver the order, thus leading the Mission to urgently look for another supplier to cater for its urgent logistic requirements. Besides, the partially delivered goods were of poor quality resulting in increasing the dissatisfaction of endusers and queries about the vendor's evaluation and capacity to meet its contractual obligations with MONUSCO.

Table 16: Effect of Failure by the Vendor to Deliver on Time on Operations of Respective Sections

\begin{tabular}{lccc}
\hline Statement & Response & Frequency & Percent \\
\hline & Strongly Disagree & 95 & 71.4 \\
& Disagree & 23 & 17.3 \\
& Neutral & 8 & 6.0 \\
Failure by the vendor to deliver on time & Agree & 4 & 3.0 \\
does not affect operations in my & Strongly Agree & 3 & 2.3 \\
section & Total & $\mathbf{1 3 3}$ & $\mathbf{1 0 0 . 0}$ \\
\hline
\end{tabular}

\subsection{Levels of Service Delivery at MONUSCO ESB}

Helmsing (1995) in his study defines service delivery as a deliberate obligatory decision by the elected or appointed officials to serve or deliver goods and services to the recipients. This section examined and presented findings on levels of service delivery at MONUSCO ESB. The study findings are presented in the preceding tables.

\subsubsection{Satisfaction with the Quality of Services/Goods Offered in MONUSCO}

Christopher (2002) observed that variables, in each purchasing process and decision are: quality, delivery and price service package. It is against these variables that the procurement entity has basically to function within in order to satisfy its internal customers, the end-users. The respondents were asked to opine whether they are satisfied with the quality of services/goods offered in MONUSCO and responses obtained are summarised in the Table 17: 
International Journal of Supply Chain and Logistics ISSN 2520-3983 (Online)

Vol.1, Issue 2, pp 82 - 112, 2017

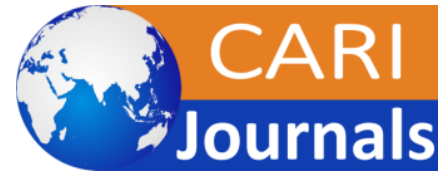

WWW.carijournals.org

Table 17: Satisfaction with the Quality of Services/Goods Offered in MONUSCO

\begin{tabular}{lccc}
\hline Statement & Response & Frequency & Percent \\
\hline & Strongly Disagree & 5 & 3.8 \\
& Disagree & 62 & 46.6 \\
& Neutral & 16 & 12.0 \\
& Agree & 48 & 36.1 \\
I am satisfied with the quality of & Strongly Agree & 2 & 1.5 \\
services/goods offered in MONUSCO & Total & $\mathbf{1 3 3}$ & $\mathbf{1 0 0 . 0}$ \\
\hline
\end{tabular}

Results in the table above show that, 5 (3.8\%) strongly disagreed, 62 (46.6\%) disagreed, 16 (12\%) were neutral, $48(36.1 \%)$ agreed and $2(1.5 \%)$ of them strongly agreed. Results obtained indicate that $67(50.4 \%)$ of the respondents generally disagreed that they are satisfied with the quality of services/goods offered in MONUSCO. Results obtained indicate that indeed some staff are satisfied with the quality of services/goods offered in MONUSCO. During the interviews, respondents revealed that "failure by the vendor to deliver on time and the delivery of poor quality materials has caused dissatisfaction amongst the user departments in MONUSCO". A review of MONUSCO documents revealed that for example the Regional Training Centre and Conference (RTCC) interoffice Memorandum of 13 November 2011 raised several complaints from training participants about the quality of pens. Consequently, 15,000 pens valuing USD \$5, 100.00 were returned to stock and thereafter disposed of. This has led to increased dissatisfaction amongst end-users at MONUSCO.

\subsubsection{Ability to Offer What End-Users Request in Respective Sections}

The respondents were asked to opine whether their sections are able to offer what end-users request for in MONUSCO and responses obtained are summarised in the Table 18. Results in the table above show that, 2 (1.5\%) strongly disagreed, 43 (32.3\%) disagreed, $23(17.3 \%)$ were neutral, $59(44.4 \%)$ agreed and $6(4.5 \%)$ of them strongly agreed. Results obtained indicate that $65(48.9 \%)$ of the respondents generally disagreed that their sections are able to offer what endusers request for in MONUSCO. Results obtained indicate that indeed their sections are not fully able to offer what end-users request for in MONUSCO. During the interviews, respondents revealed that "the persistent failure by the contractors to deliver services/materials on time and the constant delivery of poor quality materials has resulted in their sections failing to offer what end-users request for in MONUSCO". This has drastically affected the service delivery levels in the user departments in MONUSCO ESB.

Table 18: Ability to Offer What End-Users Request in Respective Sections

\begin{tabular}{lccc}
\hline Statement & Response & Frequency & Percent \\
\hline & Strongly Disagree & 2 & 1.5 \\
& Disagree & 43 & 32.3 \\
& Neutral & 23 & 17.3 \\
& Agree & 59 & 44.4 \\
My section is able to offer what end-users & Strongly Agree & 6 & 4.5 \\
request & Total & $\mathbf{1 3 3}$ & $\mathbf{1 0 0 . 0}$ \\
\hline
\end{tabular}


International Journal of Supply Chain and Logistics ISSN 2520-3983 (Online)

Vol.1, Issue 2, pp 82 - 112, 2017

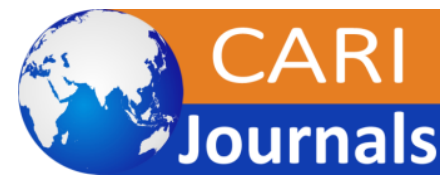

WWW.carijournals.org

\subsubsection{Complaints about the Poor Quality of Good/Service Provided among MONUSCO Staff}

The respondents were asked to opine whether indeed MONUSCO staff complains about the poor quality of good/service provided and responses obtained are summarised in the Table 19:

Table 19: Complaints about the Poor Quality of Good/Service Provided among MONUSCO Staff

\begin{tabular}{lccc}
\hline Statement & Response & Frequency & Percent \\
\hline & Strongly Disagree & 1 & .8 \\
& Disagree & 11 & 8.3 \\
& Neutral & 20 & 15.0 \\
MONUSCO staff complain about the poor & Agree & 41 & 30.8 \\
quality of good/service provided & Strongly Agree & 60 & 45.1 \\
\hline
\end{tabular}

Results in the table above show that, 1(0.8\%) strongly disagreed, $11(8.3 \%)$ disagreed, 20 $(15.0 \%)$ were neutral, $41(30.8 \%)$ agreed and $60(45.1 \%)$ of them strongly agreed. Results obtained indicate that $101(75.9 \%)$ of the respondents generally agreed that MONUSCO staff complains about the poor quality of good/service provided. Results obtained indicate that indeed MONUSCO staff complains about the poor quality of good/service provided. A review of literature from MONUSCO revealed that in 2014, following the expansion of the Regional Service Centre Entebbe (RSCE), the supply section was urgently requested to locally acquire office furniture to support the relocation of 200 staff to MONUSCO ESB. However due to the emergency procurement, the office furniture which was locally sourced which was however found to be of poor quality. This procurement exercise resulted into complaints from end-users in the respective sections of the Regional Service Centre Entebbe (RSCE).

\subsubsection{Offering of the Right Good/Service at the Right Time in MONUSCO always}

The respondents were asked to opine whether indeed MONUSCO always offers the right good/service at the right time and responses obtained are summarised in the Table 20:

Table 20: Offering of the Right Good/Service at the Right Time in MONUSCO always

\begin{tabular}{lccc}
\hline Statement & Response & Frequency & Percent \\
\hline & Strongly Disagree & 36 & 27.1 \\
& Disagree & 41 & 30.8 \\
& Neutral & 35 & 26.3 \\
& Agree & 19 & 14.3 \\
MONUSCO always offers the right & Strongly Agree & 2 & 1.5 \\
good/service at the right time & Total & $\mathbf{1 3 3}$ & $\mathbf{1 0 0 . 0}$ \\
\hline
\end{tabular}

Results in the table 20 show that, 36 (27.1\%) strongly disagreed, 41 (30.8\%) disagreed, 35 $(26.3 \%)$ were neutral, $19(14.3 \%)$ agreed and $2(1.5 \%)$ of them strongly agreed. Results obtained indicate that $78(57.9 \%)$ of the respondents generally disagreed that MONUSCO always offers the right good/service at the right time. Results obtained indicate that indeed MONUSCO does not always offer the right good/service at the right time. During the interviews, respondents 
revealed that "failure by the vendor to deliver on time and the delivery of poor quality materials has caused dissatisfaction amongst the user departments at MONUSCO". The late delivery of materials and goods needed has affected the service delivery levels in the respective sections in MONUSCO ESB.

\subsubsection{Availability of Most of the Materials Requested in the Stores}

The respondents were asked to opine whether indeed most of the materials requested are available in the stores in MONUSCO and responses obtained are summarised in the Table 21. Results in the table above show that, 2 (1.5\%) strongly disagreed, 56 (42.1\%) disagreed, 21 $(15.8 \%)$ were neutral, $49(36.8 \%)$ agreed and $5(3.8 \%)$ of them strongly agreed. Results obtained indicate that $58(43.6 \%)$ of the respondents generally disagreed that most of the materials requested are available in the stores in MONUSCO. Results obtained indicate that to some extent most of the materials requested are available in the stores in MONUSCO. During the interviews with respondents, they revealed that "sometimes some materials run out of stock thereby forcing the departments to opt for emergency procurements". This has resulted in high number of rushhour/emergency procurements in MONUSCO ESB.

Table 21: Offering of the Right Good/Service at the Right Time in MONUSCO always

\begin{tabular}{|c|c|c|c|}
\hline Statement & Response & Frequency & Percent \\
\hline \multirow{6}{*}{$\begin{array}{l}\text { Most of the materials requested are } \\
\text { available in the stores }\end{array}$} & Strongly Disagree & 2 & 1.5 \\
\hline & Disagree & 56 & 42.1 \\
\hline & Neutral & 21 & 15.8 \\
\hline & Agree & 49 & 36.8 \\
\hline & Strongly Agree & 5 & 3.8 \\
\hline & Total & 133 & 100.0 \\
\hline
\end{tabular}

4.3.6 Getting the Quantity of Items Requested in Respective Sections

The respondents were asked to further opine whether indeed in their sections they always get the quantity of items requested and responses obtained are summarised in the Table 22.

Table 22: Getting the Quantity of Items Requested in Respective Sections

\begin{tabular}{lccc}
\hline Statement & Response & Frequency & Percent \\
\hline & Strongly Disagree & 7 & 5.3 \\
& Disagree & 70 & 52.6 \\
& Neutral & 19 & 14.3 \\
In my section, I always get the quantity of & Agree & 31 & 23.3 \\
items requested & Strongly Agree & 6 & 4.5 \\
& Total & $\mathbf{1 3 3}$ & $\mathbf{1 0 0 . 0}$ \\
\hline
\end{tabular}

Results in the table above show that, 7 (5.3\%) strongly disagreed, 70 (52.6\%) disagreed, 19 (14.3\%) were neutral, $31(23.3 \%)$ agreed and $6(4.5 \%)$ of them strongly agreed. Results obtained indicate that $70(57.9 \%)$ of the respondents generally disagreed that in their sections they always get the quantity of items requested. Results obtained indicate that to some extent in their sections they do not always get the quantity of items requested. During the interviews with respondents, 
they revealed that "still sometimes there are materials which are not provided for as requested by the user departments". This has also resulted in emergency procurements in MONUSCO ESB.

\subsubsection{Taking into Consideration End-Users' Opinions and Complaints of about Poor Quality of Goods}

The respondents were also asked to opine whether MONUSCO takes into consideration endusers' opinions and complaints of about poor quality of goods and responses obtained are summarised in the Table 23.

Table 23: Taking into Consideration End-Users' Opinions and Complaints of about Poor Quality of Goods

\begin{tabular}{lccc}
\hline Statement & Response & Frequency & Percent \\
\hline & Strongly Disagree & 40 & 30.1 \\
& Disagree & 32 & 24.1 \\
& Neutral & 15 & 11.3 \\
MONUSCO takes into consideration end- & Agree & 32 & 24.1 \\
users' opinions and complaints of about & Strongly Agree & 14 & 10.5 \\
poor quality of goods & Total & $\mathbf{1 3 3}$ & $\mathbf{1 0 0 . 0}$ \\
\hline
\end{tabular}

Results in the table above show that, 40 (30.1\%) strongly disagreed, 32 (24.1\%) disagreed, 15 $(11.3 \%)$ were neutral, $32(24.1 \%)$ agreed and $14(10.5 \%)$ of them strongly agreed. Results obtained indicate that $72(54.1 \%)$ of the respondents generally disagreed that MONUSCO takes into consideration end-users' opinions and complaints of about poor quality of goods. Results obtained indicate that to a larger extent MONUSCO takes into consideration end-users' opinions and complaints of about poor quality of goods. During the interviews with respondents, they revealed that "the respective staff in these sections are invited to submit queries on contractors" services and supplier's for contract evaluation purposes at MONUSCO'. This has resulted thorough auditing of suppliers and contracts contracted with MONUSCO ESB.

\subsubsection{Consulting Staff on the Way to Improve Service/Goods Provided to End-Users}

The respondents were also asked to opine whether their sections consult them on the way to improve service/goods provided to end-users and responses obtained are summarised in the Table 24:

Table 24: Consulting Staff on the Way to Improve Service/Goods Provided to End-Users

\begin{tabular}{lccc}
\hline Statement & Response & Frequency & Percent \\
\hline & Strongly Disagree & 32 & 24.1 \\
& Disagree & 33 & 24.8 \\
& Neutral & 19 & 14.3 \\
My section consults me on the way to & Agree & 35 & 26.3 \\
improve service/goods provided to end- & Strongly Agree & 14 & 10.5 \\
users & Total & $\mathbf{1 3 3}$ & $\mathbf{1 0 0 . 0}$ \\
\hline
\end{tabular}

Results in the table above show that, 32 (24.1\%) strongly disagreed, 33 (24.8\%) disagreed, 19 $(14.3 \%)$ were neutral, $35(26.3 \%)$ agreed and $14(10.5 \%)$ of them strongly agreed. Results 
obtained indicate that $65(48.9 \%)$ of the respondents generally disagreed that their sections consults them on the way to improve service/goods provided to end-users in MONUSCO. Results obtained indicate that to a larger extent their sections consult them on the way to improve service/goods provided to end-users in MONUSCO ESB. During the interviews with respondents, they revealed that "some section staff are not consulted for their in-puts concerning the strategies' to improve on the services/materials and goods provided to the user departments".

\subsubsection{Taking Appropriate Correction Measures Against Non-Performing Vendors}

The study also asked the respondents whether MONUSCO takes appropriate correction measures against non-performing vendors at the ESB and responses obtained are shown in the Table 25.

Table 25: Taking Appropriate Correction Measures Against Non-Performing Vendors

\begin{tabular}{lccc}
\hline Statement & Response & Frequency & Percent \\
\hline & Strongly Disagree & 16 & 12.0 \\
& Disagree & 50 & 37.6 \\
& Neutral & 17 & 12.8 \\
MONUSCO takes appropriate correction & Agree & 30 & 22.6 \\
measures against non performing vendors & Strongly Agree & 20 & 15.0 \\
& Total & $\mathbf{1 3 3}$ & $\mathbf{1 0 0 . 0}$ \\
\hline
\end{tabular}

Results in the table above show that, 16 (12\%) strongly disagreed, 50 (37.6\%) disagreed, 17 $(12.8 \%)$ were neutral, $30(22.6 \%)$ agreed and $20(15.0 \%)$ of them strongly agreed. Results obtained indicate that $66(49.6 \%)$ of the respondents generally disagreed that MONUSCO takes appropriate correction measures against non-performing vendors in MONUSCO ESB. The results obtained imply that to some extent the organisation has not taken full appropriate correction measures against non-performing vendors. This has to some extent affected the service delivery levels in MONUSCO ESB.

\subsubsection{Undertaking of Supplier Audits to Correct Compliance Errors}

Procurement planning procedures may be convenient and useful tools, but the planning effort will succeed only with the complete commitment and involvement of top management. This also calls for measurement of the effectiveness to ensure proper business controls by conducting periodic supplier audits to correct compliance errors (Lisa: 2010). The study therefore asked the respondents whether supplier audits are undertaken to correct compliance errors at the ESB and responses obtained are shown in the Table 26:

Table 26: Taking Appropriate Correction Measures Against Non-Performing Vendors

\begin{tabular}{lccc}
\hline Statement & Response & Frequency & Percent \\
\hline & Strongly Disagree & 8 & 6.0 \\
& Disagree & 17 & 12.8 \\
& Neutral & 12 & 9.0 \\
Supplier audits are undertaken to correct & Agree & 70 & 52.6 \\
compliance errors & Strongly Agree & 26 & 19.5 \\
& Total & $\mathbf{1 3 3}$ & $\mathbf{1 0 0 . 0}$ \\
\hline
\end{tabular}


Results in the table above show that, 8 (6\%) strongly disagreed, $17(12.8 \%)$ disagreed, $12(9.0 \%)$ were neutral, $70(52.6 \%)$ agreed and $26(19.5 \%)$ of them strongly agreed. Results obtained indicate that $96(72.1 \%)$ of the respondents generally agreed that supplier audits are undertaken to correct compliance errors in MONUSCO ESB. The results obtained imply that indeed the user departments in collaboration with the procurement section have always conducted supplier audits for all pre-qualified vendors of MONUSCO ESB. This has reduced on the delivery of substandard materials and products as well increased adherence to compliance regulations.

\section{Hypothesis tests}

$\mathbf{H}_{\mathbf{O}}$ : There is no significant relationship between procurement process and effective and efficient service delivery in MONUSCO.

$\mathbf{H}_{\mathrm{A} \text { : }}$ There is a significant relationship between procurement process and effective and efficient service delivery in MONUSCO.

Linear regression analysis was used to test the relationships between the variables. The model summary table below shows that $\mathrm{R}$ square was $2.3 \%$ of the observed variability in effective and efficient service delivery in MONUSCO explained by the independent variables: My section defines its business needs on time, Early annual planning of requirements plays an important role in determination of acquisition of materials., Funds are available before planning is done., There is a procurement planning in my section.. $\mathrm{R}=0.152$ is the correlation coefficient between the observed value of the dependent variable and the predicted value based on the regression model.

The $\mathrm{R}^{2}(0.023)$ is the proportion of the variability in the dependent variable explained by the linear regression. The results show that procurement process contributes $0.023 \%$ to effective and efficient service delivery in MONUSCO. The remaining $97.7 \%$ is contributed by other factors outside the scope of the current study.

Table 27: Model Summary

\begin{tabular}{ccccc}
\hline Model & $\mathrm{R}$ & R Square & Adjusted R Square & $\begin{array}{c}\text { Std. Error of the } \\
\text { Estimate }\end{array}$ \\
\hline 1 & $.152^{\mathrm{a}}$ & .023 & .007 & 1.074 \\
\hline
\end{tabular}

a. Predictors: (Constant), My section defines its business needs on time, Early annual planning of requirements plays an important role in determination of acquisition of materials, Funds are available before planning is don, There is a procurement planning in my section.

The analysis-of-variance (ANOVA) was also used by the study to test the equivalent null hypothesis. The $\mathrm{F}=0.757, \mathrm{p}<0.555$, the null hypothesis that there is no significant relationship between procurement process and effective and efficient service delivery in MONUSCO was not rejected, meaning that at least one of the population regression coefficient is zero. The results indicate that there is very weak positive relationship between procurement process and effective and efficient service delivery in MONUSCO. 
International Journal of Supply Chain and Logistics ISSN 2520-3983 (Online)

Vol.1, Issue 2, pp 82 - 112, 2017

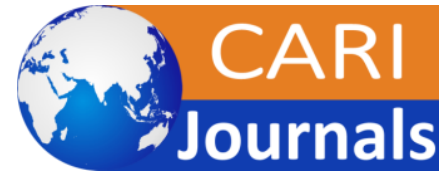

WWW.carijournals.org

Table 28: ANOVA ${ }^{\mathrm{a}}$

\begin{tabular}{ccccccc}
\hline & Model & Sum of Squares & df & Mean Square & F & Sig. \\
\hline \multirow{2}{*}{1} & Regression & 3.490 & 4 & .872 & .757 & $.555^{\mathrm{b}}$ \\
& Residual & 147.608 & 128 & 1.153 & & \\
& Total & 151.098 & 132 & & & \\
\hline
\end{tabular}

a. Dependent Variable: MONUSCO always offers the right good/service at the right time.

b. Predictors: (Constant), My section defines its business needs on time, Early annual planning of requirements plays an important role in determination of acquisition of materials. Funds are available before planning is done, There is a procurement planning in my section.

The regression matrix tests what independent variable is more important to the dependent variable. The results show that section defines its business needs on time is the most significant independent variable to effective and efficient service delivery at MONUSCO because it has a tstatistic $=1.315, \mathrm{p}<0.191$. This means that procurement process in MONUSCO contributes to service delivery to a very small extent.

Table 29: Coefficients ${ }^{\mathrm{a}}$

\begin{tabular}{|c|c|c|c|c|c|}
\hline \multirow[t]{2}{*}{ Model } & \multicolumn{2}{|c|}{$\begin{array}{l}\text { Unstandardized } \\
\text { Coefficients }\end{array}$} & \multirow{2}{*}{$\begin{array}{c}\text { Standardized } \\
\text { Coefficients } \\
\text { Beta }\end{array}$} & \multirow[t]{2}{*}{$\mathrm{t}$} & \multirow[t]{2}{*}{ Sig. } \\
\hline & B & Std. Error & & & \\
\hline (Constant) & 2.191 & .789 & & 2.776 & .006 \\
\hline $\begin{array}{l}\text { There is a procurement planning in my } \\
\text { section. }\end{array}$ & .041 & .105 & .038 & .388 & 699 \\
\hline $\begin{array}{l}\text { Funds are available before planning is } \\
\text { done. }\end{array}$ & -.011 & .092 & -.012 & -.124 & .901 \\
\hline $\begin{array}{l}\text { Early annual planning of requirements } \\
\text { plays an important role in determination } \\
\text { of acquisition of materials. }\end{array}$ & -.100 & .142 & -.062 & -.706 & .481 \\
\hline $\begin{array}{l}\text { My section defines its business needs on } \\
\text { time }\end{array}$ & .124 & .094 & .123 & 1.315 & .191 \\
\hline
\end{tabular}

\subsection{SUMMARY OF FINDINGS, CONCLUSIONS AND RECOMMENDATIONS}

\subsection{Summary of Findings}

The current study established that, $110(82.7 \%)$ of the respondents generally agreed that indeed contract is awarded to suppliers who meet our products/materials technical specifications. During the interviews, respondents revealed "the suppliers are awarded contracts based on their level of meeting the product/materials technical specifications". This has ensured clear meeting of product standards and service delivery in all MONUSCO user departments. It was also revealed from the research findings that $95(71.2 \%)$ of the respondents generally agreed that Contracts are awarded to vendors who offer lower price. During the interviews respondents revealed "the suppliers are awarded contracts based on the lowest price offers for the various services and goods to be procured by MONUSCO user departments in Entebbe Support Base". This implies that the bidder with the lowest price is always considered for contract award in MONUSCO ESB. 
The study findings further revealed that 78 (58.6\%) of the respondents generally disagreed that MONUSCO vendors meet all the terms of contracts. During the interviews respondents revealed "in some cases, some suppliers are awarded contracts yet they do not meet all the contract terms as agreed by the contract committee". This implies that some vendors do not meet all the terms of contracts as agreed at the time of contract award at the MONUSCO ESB. Also according to the study findings, it was showed that 69 (51.9\%) of the respondents generally disagreed that they are happy with the vendors their section deals with at MONUSCO. The results obtained imply that to a larger extent the staffs of MONUSCO are not very happy with the vendors their respective section deals with. This means the vendors do not adequately meet the contract terms and conditions which affects service delivery in the user departments of MONUSCO ESB. However, the study also established that 118 (88.7\%) of the respondents generally agreed that all vendors have a clear delivery schedule in MONUSCO ESB. The results obtained imply that to a larger extent most vendors have a delivery schedule as per the user department requirements. This means that the vendors draw and share the supply delivery schedule with the user departments in MONUSCO ESB.

The study went ahead and established that 66 (49.6\%) of the respondents generally disagreed that MONUSCO takes appropriate correction measures against non performing vendors in MONUSCO ESB. The results obtained imply that to some extent the organization has not taken full appropriate correction measures against non performing vendors. This has to some extent affected the service delivery levels of MONUSCO Entebbe Support Base. The study further revealed that $64(48.1 \%)$ of the respondents generally disagreed that they are fully aware of the delivery times for materials in their respective sections in MONUSCO ESB. The results obtained imply that some staff of MONUCO are not aware of the delivery schedules for materials used in the emergency operations or planned peacekeeping operations. The results obtained imply that to a greater extent they are not fully involved in the delivery scheduling of the procurement activities.

\subsubsection{Levels of Service Delivery in MONUSCO ESB}

The current study established that, 67 (50.4\%) of the respondents generally disagreed that they are satisfied with the quality of services/goods offered in MONUSCO. Results obtained indicate that indeed some staff are satisfied with the quality of services/goods offered in MONUSCO. During the interviews, respondents revealed that "failure by the vendor to deliver on time and the delivery of poor quality materials has caused dissatisfaction amongst the user departments at MONUSCO”.

The study went further to establish that, 65 (48.9\%) of the respondents generally disagreed that their sections are able to offer what end-users request for at MONUSCO. Results obtained indicate that indeed their sections are not fully able to offer what end-users request for in MONUSCO. During the interviews, respondents revealed that "the persistent failure by the contractors to deliver services/materials on time and the constant delivery of poor quality materials has resulted in their sections failing to offer what end-users request for at MONUSCO". This has drastically affected the service delivery levels in the user departments in MONUSCO Entebbe Support Base.

Results from the study findings revealed that 101 (75.9\%) of the respondents generally agreed that MONUSCO staff complains about the poor quality of good/service provided. Results 
obtained indicate that indeed MONUSCO staff complains about the poor quality of good/service provided. Findings from the current study also established that $78(57.9 \%)$ of the respondents generally disagreed that MONUSCO always offers the right good/service at the right time. Results obtained indicate that indeed MONUSCO does not always offer the right good/service at the right time. During the interviews, respondents revealed that "failure by the vendor to deliver on time and the delivery of poor quality materials has caused dissatisfaction amongst the user departments in MONUSCO”. The late delivery of materials and goods needed has affected the service delivery levels in the respective sections in the Regional Service Centre Entebbe (RSCE) in particular and in MONUSCO ESB in particular.

The study findings also revealed that $58(43.6 \%)$ of the respondents generally disagreed that most of the materials requested are available in the stores in MONUSCO. Results obtained indicate that to some extent most of the materials requested are available in the stores in MONUSCO. During the interviews with respondents', they revealed that "sometimes some materials run out of stock thereby forcing the departments to opt for emergency procurements". This has resulted in high number of rush-hour/emergency procurements in MONUSCO.

The study findings further revealed that 77 (57.9\%) of the respondents generally disagreed that in their sections they always get the quantity of items requested. Results obtained indicate that to some extent in their sections they do not always get the quantity of items requested. During the interviews with respondents, they revealed that "still sometimes there are materials which are not provided for as requested by the user departments". This has also resulted in emergency procurements in MONUSCO ESB.

\subsection{Conclusion}

The results show that procurement process contributes $2.3 \%$ to effective and efficient service delivery in MONUSCO. The remaining $97.7 \%$ is contributed by other factors outside the scope of the current study such as sharing vendor rosters, common specifications, procurement audits, contract Evaluation and monitoring among other factors. Hence, the study concludes that there is a very weak positive relationship between procurement process and service delivery in MONUSCO ESB.

\subsection{Recommendations}

The study recommends MONUSCO procurement section to adequately select the right suppliers to provide the required goods and services. The organization should establish agreements with suppliers with clear guidelines on operations during service delivery. It is also recommended that the management needs to ensure that the procurement activities are accomplished in line with the outcome measures. MONUSCO Entebbe Support Base should focus on implementing strict procurement practices that must be followed with contract value thresholds dictating the procurement practices to be adopted by all MONUSCO sections.

\section{REFERENCES}

Adams, B. \& Colebourne, P. (1989). The role of financial management in service organizations. In: P. Jones (Ed.) Management in Service Industries (London, Pitman Publishing), pp. 223-233. 
Agaba, E., \& Shipman, N. (2007). Public procurement reform in developing countries: The Ugandan experience. Advancing Public Procurement: Practices, Innovation and Knowledge-Sharing, 373-391.

Armstrong, M. (2001). A hand book of human resource management, ( $8^{\text {th }}$ ed.). Kogan Page London, UK.

Bailey, P., Farmer, D., Jessop, D., \& Jones, D. (1998). Purchasing principles and management, ( $8^{\text {th }}$ ed.). Edinburgh, Prentice Hall.

Baily, P., Farmer, D., Jessop D., \& Jones, D. (2005). Purchasing principles and management. UK.: Pearson education Limited.

Balunywa, M. (2004). Decentralization and service delivery in Uganda: The case of contracting out road construction services in Jinja District. Kampala. Makerere University Library.

Basheka, B. (2004). Procurement planning and local governance in Uganda: A factor analysis approach. Organisation: Uganda Management institute.

Basheka, B. C. (2008). Procurement planning and local governance in Uganda: A factor analysis approach. Paper Presented at the 2008 International Research Society for Public Management Conference, from 26-28 March 2008, in Brisbarne, Australia.

Basheka, B. C., (2008). Procurement planning and accountability of local Government procurement systems in developing countries: Evidence from Uganda, Journal of Public Procurement, 8(3), 379 - 406.

Bashuna, A. (2013). Factors affecting effective management of the procurement function at Nakuru North Sub-County, International Journal of Business and Management, 1(7).

Brammer, S., \& Walker, H. (2007). Sustainable procurement in the United Kingdom public sector. University of Bath School of Management Working Paper Series.

Chartered institute of Purchasing and Supply Austria, 2005

Defee, C., Williams, B., Randall, W. S., \& Thomas, R. (2010). An inventory of theory in logistics and SCM research. The International Journal of Logistics Management, 21(93), 404-489.

Demchenko, Y. (2009). Service delivery framework and services lifecycle management in ondemand services/resources provisioning, WP 2/W P3 Technical document, Version 0.2

Development Assistance Committee (2005). Harmonizing donor practices for effective aid delivery. Vol. 3. Strengthening procurement capacities in developing countries. Paris, France: OECD Development Assistance Committee, 2005; 18. 
Godfrey, A. B. (2012). Purpose driven research? The critical key to successful partnerships. proceedings of 2012 AUTEX World Technical Conference. Publisher: Association of Universities of Textiles: Ghent, BE.

Helmsing, A. H. J. (1995). Local government central finance: An introduction. New York USA.

Helmsing, J. (1995). Decentralisation and emerging patterns of local governance: A comparative analysis of Uganda, Zimbabwe and Zambia. Institute of social studies (ISS).

Hernon, P., \& Whitman, J. R. (2001). Delivering satisfaction and service quality: A customerbased approach for libraries. Chicago: American Library Association.

Hui, W. S., Othman, O., Rahman, R. A., \& Haron, N. H. (2011). Procurement issues in Malaysia. International Journal of Public Sector management, 24(6), 567-593.

Ishola T.O, (2010). Procurement and supply management. National Open University of Nigeria.

Johan, N. (2006). Planning for service delivery improvement. S D R Vol. 15(2), 106-109.

Kansiime, Apollo (2013). The impact of public procurement reforms on service delivery in Uganda. A case study of Kabale Municipality, Kabale district.

Kattel, R., \& Lember, V. (2010). Public procurement as an industrial policy tool: An option for developing countries? Journal of Public Procurement, 10(3), 368-404

Kelley, D., Bosma, N. S., Amorós, J. E. B. (2011). Global Entrepreneurship Monitor 2010 Executive Report, Utrecht University Repository (Report)

Khattab, A. S. (2005). The impact of information technology on customer services in Jordanian banking sector: University of Salford.

Knack, S., \& Rahman, A. (2009). Donor fragmentation and bureaucratic quality in aid recipients. Journal of Development Economics, 83(1), 176-97.

Lisa, I. (2010). Compliance culture: A conceptual framework. Journal of management and organization, 19 (7), 702-714.

Lysons, K., \& Farrington, B. (2006). Purchasing and supply chain management (7 ${ }^{\text {th }}$ ed.). Prentice Hall, FT.

Nichols, P. (2002). Regulating transnational bribery in times of globalization and fragmentation. The Yale Journal of Internal law, 24(1), 257-304. 
Nyeko, P. K., \& Kakwezi, P. (2004). Procurement Processes and Performance: Efficiency and Effectiveness of the Procurement Function. International Journal of Business and Commerce, 3(1), 54-70.

Obanda, W. (2011). Small and medium enterprises (SMEs) and public procurement contract in developing countries. Kampala: Longhorn publishers.

Obanda, W. P. (2010). Fighting corruption in tactical procurement. PHD dissertation.

Oboth, M. J. (2001). Decentralization and service delivery: Constraints and controversies. Kampala: Makerere University Library.

OECD, (2005). Harmonizing donor practices for effective aid delivery: Strengthening procurement capacities in developing countries, Development Assistance Committee, Vol. 3. Paris, France.

Parasuraman, A., Berry, L. L., \& Zeithaml, A. V. (1996). The behavioural consequences of service quality. Financial Times.

Parasuraman, A., Zeithaml, A., \& Berry, L. (1993). Research note: More on improving service quality measurement, Journal of Retailing, (1), 140-7.

Scott, W. Richard (2004). Institutional theory. Pp. 408-14 in Encyclopaedia of Social Theory, George Ritzer, ed. Thousand Oaks, CA: Sage

Simchi-Levi, D., Simchi-Levi, E., \& Kaminsky, P. (1999). Designing and managing the supply chain: Concepts, strategies, and cases. New York: McGraw-Hill.

Sutinen, J. G \& Kuperan, K. (1999). A Socio-economic theory of regulatory compliance. International Journal of Social Economics, 26 (1/2/3), 174-193

Thai, K. V. (2009). Introduction to Public Procurement, (5 ${ }^{\text {th }}$ ed.). Florida Atlantic University.

Tumugabiirwe, K. (2011). Procurement planning and service delivery in Local Government: A case study of Ibanda Town Council.

UN Procurement Practitioner's Handbook, 2006.

United Nations Procurement Manual, Revision 7 (2013), Department of Management, Office of Central Support Services, Procurement Division.

World Bank Institute (WBI) and Public-Private Infrastructure Advisory Facility (PPIAF), (2013). Value-for-money analysis practices and challenges: How governments choose when to Use PPP to deliver public infrastructure and services. Report from World Bank Global Round-Table 28 May, 2013, Washington DC. 